\title{
Analysis of Student Satisfaction in the Current Online Teaching Scenario
}

\author{
Anish Nair ${ }^{1}$, Radeep Krishna Radhakrishnan Nair ${ }^{2}$ \\ ${ }^{1}$ Department of Mechanical Engineering, ${ }^{2}$ Kalasalingam Academy of Research and Education, Krishnankoil - 626126, India \\ ${ }^{2}$ Department of Electronics and Communication Engineering, ${ }^{2}$ Kalasalingam Academy of Research and Education, \\ Krishnankoil - 626126, India \\ 1 anish@klu.ac.in \\ ${ }^{2}$ r.radeepkrishna@klu.ac.in
}

\begin{abstract}
The current COVID situation has put the entire education system in a state of shock and has forced the educators to adopt online teaching at a rapid pace. Faculty and students are working hard to adapt to new and continuously evolving methods of and to make it as close to a classroom experience as possible. Hence an analysis of student satisfaction for a specific course is planned through analytical means in this article. Data is collected using the distance education learning environments survey as it closely resembles the current online teaching scenario. The survey captures the relationship between student satisfaction and parameters such as faculty support, student interaction, active learning, student autonomy, authentic learning and personal relevance. The survey is designed as a five point Likert type set of choices for each of the parameters. The participants of this study were 150 undergraduate students of Second year of Kalasalingam Academy of Research and Education who were taking a common course in Mathematics. From the survey results, correlation analysis and descriptive statistics is conducted to understand the parameters which considerably affect the student satisfaction considerably. The analysis shows that faculty interaction and student interaction were the most significant factors affecting student satisfaction. These results can directly act as an input to the institutions which are finding the aspect of online classes challenging and will motivate them to address the key issues directly to improve their student satisfaction.
\end{abstract}

Keywords: Likert, online teaching, correlation analysis, online education learning environment survey

\author{
Anish Nair \\ Department of Mechanical Engineering, Kalasalingam \\ Academy of Research and Education, Krishnankoil - \\ 626126, India \\ anish@klu.ac.in
}

\section{Introduction}

Education system world over was suddenly brought to a halt due to the COVID-19 pandemic. We all have had to move on and adapt to online teaching and learning, and it has, in a big way, ensured that Education in schools, colleges and in all institutions goes on in a seamless manner. Given the current situation, students and teachers alike from all over the world have adapted to various online teaching and learning tools in the quickest time frame possible.

Though online courses have been available for a few years now, the current scale of synchronous online teaching and learning is unprecedented. New online teaching and learning tools are available every day and the existing tools are seeing significant updates as well. In our University, we have been keeping ourselves updated on all the up and coming teaching tools and have implemented Online instructions for all our classes across all the colleges in our University. We have ensured that the student education goes on seamlessly and have replicated and bettered the Student Classroom experience via our online classrooms.

Though online teaching has helped us keep our classes going, there has been one noticeable demerit of the same. Since both teachers and students are new to the online mode of instruction, it has been proving difficult for teachers to gauge student satisfaction from online classes. This paper deals with studying student satisfaction in online teaching. Studies on distance and online learning have already been conducted by various authors and some of them have been discussed here. A study related to online doctoral programmes describing the experience of the students was reported ( $\tilde{A}$, Kleiner and Hess, 2006). It was observed that students had same positive experiences as a regular classroom setting. The various factors affecting student preferences was compared in detail in both online and traditional learning environments (Beyth-Marom et al., 2003). Here the selection of the mode of teaching was completely governed by the students and it was not a situation where in forceful implementation had to be done. Hence, the results showed that the students who preferred online teaching wanted more autonomy in their day to day affairs unlike the students who opted for offline teaching. Various mechanisms have been discussed for gathering the data related to student satisfaction and the student participation through Online Discussion Forums for Distance education (da Silva, Barbosa and Gomes, 2019). 
The major conclusions were that the student interaction is on a higher and better side in the initial teaching sessions but it diminishes in the subsequent semesters. Hence measures have to be taken to ensure that the student participation remains constant throughout the duration of the programme. Major factors usually affecting the student satisfaction are directly related to the instructor and the way the student perceives the technology (Hermans, Haytko and Mott-stenerson, 2009). The implications of synchronous and asynchronous teaching methods was discussed and it was observed that synchronous learning provides a chance for the faculty to interact with the students, which is not usually not possible in asynchronous teaching. Studies were reported also for individual courses where the comparison between face to face and e-learning methods was applied and it was reported that both face to face and Online learning methods were equally effective (Kalpokaite and Radivojevic, 2020). Work related to Student satisfaction prediction has been carried out and reported (Kuo et al., 2013). It was shown that learner-instructor interaction, learner-content interaction and internet self-efficacy were the major factors that contributed to student satisfaction. Gender and duration of online engagement also seem to have an influence on the above 3 factors. Various software tools have been successfully employed by authors for the measurement of student satisfaction (Mahmud, Khan and Lima, 2018). The results from those tools revealed that teaching quality and learning resources played an important role in the satisfaction of the students. The article also reflected a poor relationship between student satisfaction and curriculum satisfaction. The various interactions that are frequently associated with student satisfaction were described where in learner-learner interaction, studentstudent interaction and student-content interaction were the most important and critical (Moore, 1989). Regression and other statistical methods have been successfully employed by various authors for studying the dependency of various factors on student satisfaction. (Palmer and Holt, 2009), Palmer and Holt (2009) reported such an article where they found that 5 items significantly contributed to the development of the student satisfaction model. Such interactions have been studied by authors and learnerlearner interaction was focussed in a study by (Sharp and Huett, 2005) for distance education and the significance of the interaction on student satisfaction was emphasized. Adapting to student needs, using meaningful examples, motivation, facilitation, delivery, communication are the keywords that have showed great weightage in motivating effective teaching among students (Young, 2010). The use of surveys is the most common form for gathering information from students in order to understand the student behaviour. Different questionnaires have been displayed in various literatures. The questionnaires are usually done in the Likert scale and then these are converted into numbers for further analysis (Strong, 2012). Distance Education Learning Environment Survey is also one of the commonly used parameters for deciding the sub-scales in each of the factors affecting student satisfaction(Walker and Fraser, 2005). Other than regression and other statistical techniques machine learning has also been used for the improvement of online education model (Villegas-Ch, Román-Cañizares and Palacios-Pacheco, 2020). The authors proposed the integration of machine learning with learning management systems in order to improve student satisfaction.

\section{Purpose and Objective:}

As can be seen from the literature survey, several studies have been reported related to student satisfaction. But most of the studies have been conducted for the traditional distance education courses where the student is already aware that they are going to pursue the course via online instruction. The current situation however has necessitated online teaching and learning and the level of student preparedness for the same is not high. Hence the reflection of student satisfaction in such a scenario needs attention. This article was developed to reflect the student perspective on the current online education methods which are being followed in our University. The transition to online teaching was not planned and both the faculty and students had to get used to a lot of things in a quick way in order to conduct the classes online in a resourceful way. Hence a student perception survey was conducted in order to understand the various arenas where the student faces difficulty and the areas where the student has already placed him in a comfortable position. Various factors were taken into consideration for the survey which included the facultystudent interaction, student-student interaction among the others. Satisfaction of the students also was described on the basis of 5 indices. Based on the satisfaction of the students the various factors affecting the same have been deduced in this article and have been reported.

\section{Methodology}

The basic constructs which were used for the purpose of the survey were 'Faculty-Student Interaction', 'StudentStudent Interaction', 'Students' Personal Behaviour', 'Real world learning', 'Student learning strategy', 'Student Learning Approach'. Each of these scales were further divided into subscales and these subscales have been represented in the surveys. The surveys were delivered online through Google Forms. The link for the surveys were shared through student groups. A total of 150 responses were expected from the students. The empty and incomplete responses were removed and the total number of responses for this survey stood at 112 . Hence $75 \%$ of the total responses were considered for the further analysis. Each of the questions were posed to the students in a 5 point Likert scale in the form 5 - Always, 4 -Often, 3 - Sometimes, Seldom -2 and Never -1 . Faculty student interaction consisted of 8 subscales, Student-Student interaction comprised of 6 subscales, Students' personal behaviour comprised of 7 subscales, real world learning comprised of 5 subscales, Student learning strategy comprised of 3 subscales, Student learning approach comprised of 5 subscales and Student learning approach comprises of 5 subscales. Table 1 indicates the mean and standard deviation of the various responses collected for the individual factors.

\section{Findings}


It was observed that "Faculty-student interaction" had the highest rating followed by "Student-Learning Approach" affecting the overall student satisfaction. "Student-Student Interaction" was on the lower side with an average of 3.68 .

Table 1 Statistics for factors used in the survey

\begin{tabular}{|l|c|c|c|c|}
\hline Constructs & $\begin{array}{c}\text { No. of } \\
\text { subscales }\end{array}$ & $\begin{array}{c}\text { Surveys } \\
\text { collected }\end{array}$ & Mean & $\begin{array}{c}\text { Standard } \\
\text { Deviation }\end{array}$ \\
\hline $\begin{array}{l}\text { Faculty- } \\
\text { Student } \\
\text { Interaction }\end{array}$ & 8 & 112 & 4.40 & 1.05 \\
\hline $\begin{array}{l}\text { Student- } \\
\text { Student } \\
\text { Interaction }\end{array}$ & 6 & 112 & 3.68 & 1.26 \\
\hline $\begin{array}{l}\text { Students' } \\
\text { Personal } \\
\text { Behaviour }\end{array}$ & 7 & 112 & 3.71 & 1.71 \\
\hline $\begin{array}{l}\text { Real world } \\
\text { learning }\end{array}$ & 5 & 112 & 3.80 & 1.17 \\
\hline $\begin{array}{l}\text { Student } \\
\text { learning } \\
\text { strategy }\end{array}$ & 3 & 112 & 4.18 & 1.09 \\
\hline $\begin{array}{l}\text { Student } \\
\text { Learning } \\
\text { Approach }\end{array}$ & 5 & 112 & 4.35 & 1.05 \\
\hline $\begin{array}{l}\text { Student } \\
\text { Satisfaction }\end{array}$ & 5 & 112 & 3.00 & 1.47 \\
\hline
\end{tabular}

The eight subscales for Faculty-Student interaction have been represented in the Table 2. The highest rating as per the mean calculation represents that "Faculty being approachable" had the highest rating among the students followed by 3 other factors. The feedback regarding "Faculty feedback on assignments" was seen to be lagging from the survey analysis. The results of the "FacultyStudent Interaction" is better represented through the Figure 1.

Table 2 Statistics for Faculty-Student interaction

\begin{tabular}{|l|c|c|c|}
\hline \multicolumn{1}{|c|}{ Factors } & N & Mean & $\begin{array}{c}\text { Standard } \\
\text { Deviation }\end{array}$ \\
\hline $\begin{array}{l}\text { Faculty finds time to } \\
\text { respond to my queries }\end{array}$ & 112 & 4.48 & 1.17 \\
\hline $\begin{array}{l}\text { Faculty helps me } \\
\text { identify problem areas } \\
\text { in my study. }\end{array}$ & 112 & 4.57 & 1.00 \\
\hline $\begin{array}{l}\text { Faculty responds } \\
\text { promptly to my } \\
\text { questions. }\end{array}$ & 112 & 4.57 & 0.98 \\
\hline $\begin{array}{l}\text { Faculty gives me } \\
\text { feedback on my } \\
\text { assignments. }\end{array}$ & 112 & 4.00 & 1.06 \\
\hline $\begin{array}{l}\text { Faculty adequately } \\
\text { addresses my } \\
\text { questions. }\end{array}$ & 112 & 4.30 & 0.91 \\
\hline
\end{tabular}

\begin{tabular}{|l|c|c|c|}
\hline $\begin{array}{l}\text { Faculty encourages } \\
\text { my participation in the } \\
\text { class }\end{array}$ & 112 & 4.57 & 0.91 \\
\hline $\begin{array}{l}\text { Faculty is } \\
\text { approachable and it is } \\
\text { easy to contact the } \\
\text { faculty. }\end{array}$ & 112 & 4.59 & 0.94 \\
\hline $\begin{array}{l}\text { Faculty provides me } \\
\text { with constructive } \\
\text { feedback on my work. }\end{array}$ & 112 & 4.07 & 1.24 \\
\hline
\end{tabular}

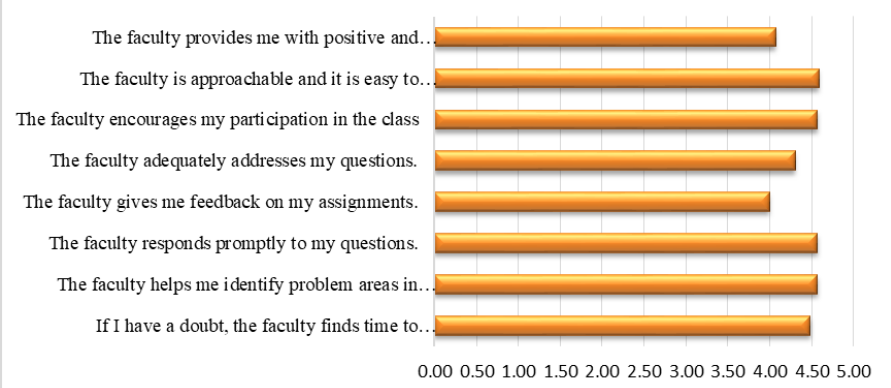

Fig. 1 Faculty-Student interaction

The response for the six subsets under "Student-Student Interaction" have been statistically described in Table 3. "Student-Student Interaction had the lowest rating among the other factors and it is observed here that the student is not sufficiently comparing his work with others for the class related activities. Also emphasis on group work is also low as it has the second least scores among the subscales. The statistics for "Student-Student Interaction have been better described in Figure 2.

Table 3 Statistics for Student-Student Interaction

\begin{tabular}{|l|c|c|c|}
\hline \multicolumn{1}{|c|}{ Factors } & N & Mean & $\begin{array}{c}\text { Standard } \\
\text { Deviation }\end{array}$ \\
\hline $\begin{array}{l}\text { I work with the others } \\
\text { in my class }\end{array}$ & 112 & 3.55 & 1.20 \\
\hline $\begin{array}{l}\text { I relate/compare my } \\
\text { work to others' work. }\end{array}$ & 112 & 3.11 & 1.44 \\
\hline $\begin{array}{l}\text { I share information } \\
\text { with other students. }\end{array}$ & 112 & 3.98 & 1.19 \\
\hline $\begin{array}{l}\text { I discuss my ideas } \\
\text { with other students. }\end{array}$ & 112 & 4.00 & 1.02 \\
\hline $\begin{array}{l}\text { I collaborate with } \\
\text { other students in the } \\
\text { class. }\end{array}$ & 112 & 3.88 & 1.14 \\
\hline $\begin{array}{l}\text { Group work is a part } \\
\text { of my activities. }\end{array}$ & 112 & 3.57 & 1.30 \\
\hline
\end{tabular}

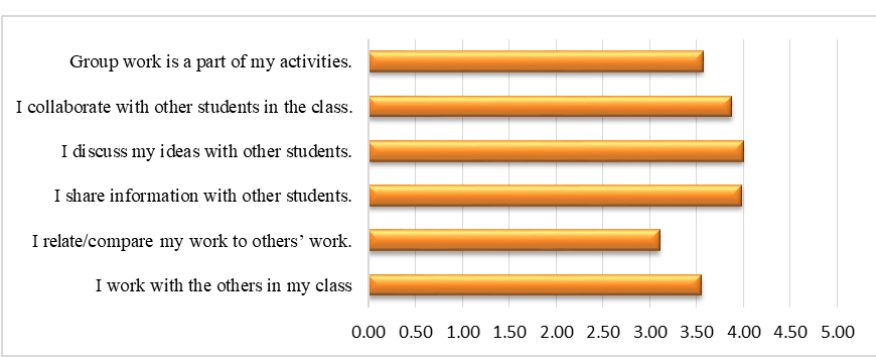

Fig. 2 Student-Student Interaction 
The statistics for "Students' Personal behaviour" have been tabulated and illustrated in Table 4 and Figure 3 respectively. It can be observed that the student is unable to relate his subject to his life outside of the university. This is an issue which is of concern as in a good learning environment the student has to be able to relate his class activities to his life outside of the university in his day to day activities. This shall provide a better reflection of the theory which is taught in class in a much practical way.

Table 4 Statistics for Students' Personal Behaviour

\begin{tabular}{|l|c|c|c|}
\hline \multicolumn{1}{|c|}{ Factors } & N & Mean & $\begin{array}{c}\text { Standard } \\
\text { Deviation }\end{array}$ \\
\hline $\begin{array}{l}\text { I can relate what } \\
\text { I learn to my life } \\
\text { outside of } \\
\text { university }\end{array}$ & 112 & 3.63 & 1.16 \\
\hline $\begin{array}{l}\text { I am able to } \\
\text { pursue topics that } \\
\text { interest me }\end{array}$ & 112 & 4.14 & 1.08 \\
\hline $\begin{array}{l}\text { I can connect my } \\
\text { studies to my } \\
\text { activities outside } \\
\text { of class }\end{array}$ & 112 & 3.63 & 1.19 \\
\hline $\begin{array}{l}\text { I apply my } \\
\text { everyday } \\
\text { experiences in } \\
\text { class }\end{array}$ & 112 & 3.52 & 1.20 \\
\hline $\begin{array}{l}\text { I link class work } \\
\text { to my life outside } \\
\text { of university }\end{array}$ & 112 & 3.27 & 1.10 \\
\hline $\begin{array}{l}\text { I learn things } \\
\text { about the world } \\
\text { outside of } \\
\text { university }\end{array}$ & 112 & 4.05 & 1.13 \\
\hline $\begin{array}{l}\text { I apply my out- } \\
\text { of-class } \\
\text { experience }\end{array}$ & 112 & 3.75 \\
\hline
\end{tabular}

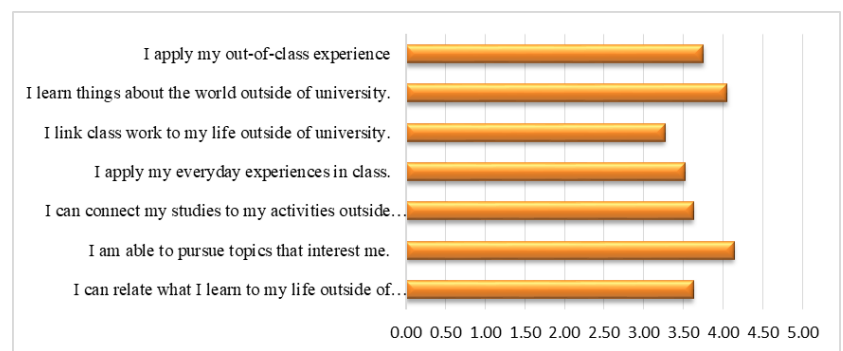

Fig. 3 Students' Personal Behaviour

The statistics for real world learning which comprises of 5 subscales is represented in Table 5 and in graphical way in Figure 4 . The overall rating by the students is less in all the subscales and the uniformity is also almost the same throughout the subscales. The course in consideration is a $3^{\text {rd }}$ semester course and it is a Mathematics subject hence it might not be a scale which the student relates to at the beginning of the program as the student is just getting used to the various concepts and terminologies. This reflects that more practical oriented sessions must be conducted such that the student is aware of the real world learning.

Table 5 Statistics for Real world learning

\begin{tabular}{|l|c|c|c|}
\hline \multicolumn{1}{|c|}{ Factors } & N & Mean & $\begin{array}{c}\text { Standard } \\
\text { Deviation }\end{array}$ \\
\hline $\begin{array}{l}\text { I study real cases } \\
\text { related to the class }\end{array}$ & 112 & 3.80 & 1.16 \\
\hline $\begin{array}{l}\text { I use real facts in } \\
\text { class activities }\end{array}$ & 112 & 3.89 & 1.03 \\
\hline $\begin{array}{l}\text { I work on } \\
\text { assignments dealing } \\
\text { with real-world } \\
\text { information }\end{array}$ & 112 & 3.84 & 1.24 \\
\hline $\begin{array}{l}\text { I work with real } \\
\text { examples }\end{array}$ & 112 & 3.75 & 1.16 \\
\hline $\begin{array}{l}\text { I enter the real world } \\
\text { of the topic of study }\end{array}$ & 112 & 3.73 & 1.25 \\
\hline
\end{tabular}

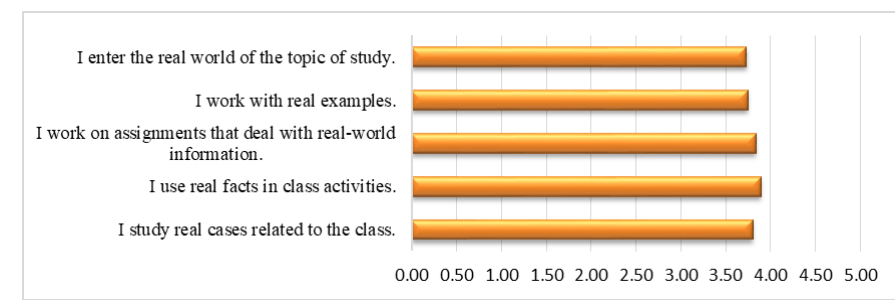

Fig. 4 Mean of the subscales - Real world learning

The results for "Student-Learning Strategy" have been tabulated in Table 6 and represented graphically in Figure 5. This is the scale with the least number of subscales and the results show that all the three subscales have been uniformly rated high.

Table 6 Statistics for Student learning strategy

\begin{tabular}{|l|c|c|c|}
\hline \multicolumn{1}{|c|}{ Factors } & N & Mean & $\begin{array}{c}\text { Standard } \\
\text { Deviation }\end{array}$ \\
\hline $\begin{array}{l}\text { I explore my own } \\
\text { strategies for } \\
\text { learning }\end{array}$ & 112 & 4.25 & 0.97 \\
\hline $\begin{array}{l}\text { I seek my own } \\
\text { answers }\end{array}$ & 112 & 4.20 & 1.08 \\
\hline $\begin{array}{l}\text { I solve my own } \\
\text { problems }\end{array}$ & 112 & 4.09 & 1.20 \\
\hline
\end{tabular}

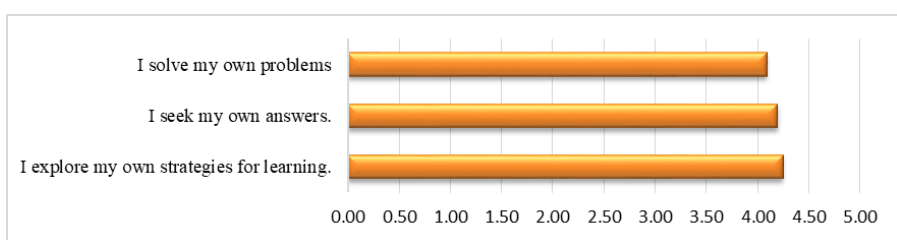

Fig. 5 Student learning strategy

The 5 subscales used for the "Student-Learning Approach" have been depicted in the Table 7 and the average of the subscales have been depicted in the Figure 6. "I am in control of my learning" is one of the factors which the students have reported a weak average of 4.09. Even these factors should not play a very important role as these factors 
can be further improved by the involvement of faculty and better interaction during the classes.

Table 7 Statistics for Student Learning Approach

\begin{tabular}{|l|c|c|c|}
\hline \multicolumn{1}{|c|}{ Factors } & N & Mean & $\begin{array}{c}\text { Standard } \\
\text { Deviation }\end{array}$ \\
\hline $\begin{array}{l}\text { I make decisions } \\
\text { about my learning }\end{array}$ & 112 & 4.48 & 0.95 \\
\hline $\begin{array}{l}\text { I work during times } \\
\text { that I find } \\
\text { convenient }\end{array}$ & 112 & 4.45 & 0.97 \\
\hline $\begin{array}{l}\text { I am in control of } \\
\text { my learning }\end{array}$ & 112 & 4.09 & 1.23 \\
\hline $\begin{array}{l}\text { I play an important } \\
\text { role in my learning }\end{array}$ & 112 & 4.25 & 1.09 \\
\hline $\begin{array}{l}\text { I approach learning } \\
\text { in my own way }\end{array}$ & 112 & 4.48 & 0.95 \\
\hline
\end{tabular}

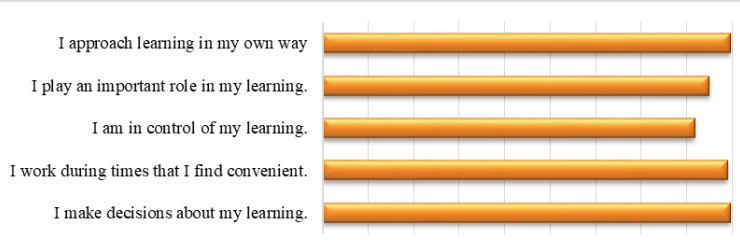

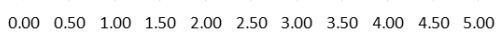

Fig. 6 Student Learning Approach

Student satisfaction is approached using 5 subscales which are shown in Table 8 . These factors can be misleading as the average of these subscales can lead to a very low result. It has to be observed that in this case the first subscale represents the actual satisfaction of the student with respect to the classes which the student is attending. The other 4 subscales are hypothetical questions which only help in understanding the student's mentality and their opinion regarding the future options of online teaching. It is pretty evident that the students have been used to offline classroom teaching for all these times and for them to completely accept and prefer online duration will take time. With that respect a rating of 3.98 for the first subscale is a very good indication and it tells that the students are comfortable with the current course and the way in which it is being handled. Hence, for further satisfaction analysis the subscale 1 has been individually taken as the response. Also, the same analysis is conducted with the aggregated satisfaction index and the results are reported.

\section{Table 8 Statistics for Student Satisfaction}

\begin{tabular}{|l|c|c|c|}
\hline \multicolumn{1}{|c|}{ Factors } & N & Mean & $\begin{array}{c}\text { Standard } \\
\text { Deviation }\end{array}$ \\
\hline $\begin{array}{l}\text { I am satisfied } \\
\text { with this program }\end{array}$ & 112 & 3.98 & 1.28 \\
\hline $\begin{array}{l}\text { Online education } \\
\text { is worth my time }\end{array}$ & 112 & 3.05 & 1.33 \\
\hline $\begin{array}{l}\text { I enjoy studying } \\
\text { online }\end{array}$ & 112 & 2.71 & 1.39 \\
\hline $\begin{array}{l}\text { Online education } \\
\text { is exciting }\end{array}$ & 112 & 2.71 & 1.30 \\
\hline
\end{tabular}

\begin{tabular}{|l|l|l|l|}
\hline $\begin{array}{l}\text { I prefer online } \\
\text { education }\end{array}$ & 112 & 2.54 & 1.58 \\
\hline
\end{tabular}

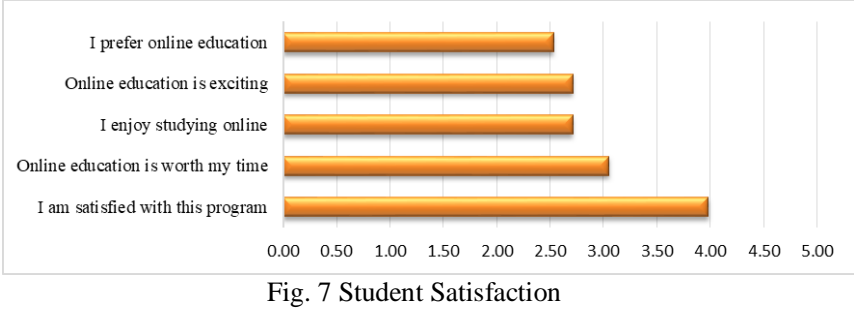

Table 9 Correlation index for the factors involved

\begin{tabular}{|l|c|c|c|c|c|c|}
\hline Factors & $\begin{array}{c}\text { Faculty- } \\
\text { Student } \\
\text { Interact } \\
\text { ion }\end{array}$ & $\begin{array}{c}\text { Student } \\
\text { - } \\
\text { Student } \\
\text { Interact } \\
\text { ion }\end{array}$ & $\begin{array}{c}\text { Students } \\
\text { Personal } \\
\text { Behaviou } \\
\text { r }\end{array}$ & $\begin{array}{c}\text { Real } \\
\text { world } \\
\text { learni } \\
\text { ng }\end{array}$ & $\begin{array}{c}\text { Stude } \\
\text { nt } \\
\text { Learni } \\
\text { ng } \\
\text { Strate } \\
\text { gy }\end{array}$ & $\begin{array}{c}\text { Student } \\
\text { learning } \\
\text { approac } \\
\text { h }\end{array}$ \\
\hline $\begin{array}{l}\text { Student- } \\
\text { Student } \\
\text { Interaction }\end{array}$ & 0.357 & - & - & - & - & - \\
\hline $\begin{array}{l}\text { Students' } \\
\text { Personal } \\
\text { Behaviour }\end{array}$ & 0.325 & 0.715 & - & - & - & - \\
\hline $\begin{array}{l}\text { Real } \\
\text { world } \\
\text { learning }\end{array}$ & 0.333 & 0.604 & 0.674 & - & - & - \\
\hline $\begin{array}{l}\text { Student } \\
\text { Learning } \\
\text { Strategy }\end{array}$ & 0.533 & 0.464 & 0.449 & 0.595 & - & - \\
\hline $\begin{array}{l}\text { Student } \\
\text { learning } \\
\text { approach }\end{array}$ & 0.566 & 0.467 & 0.450 & 0.531 & 0.757 & - \\
\hline $\begin{array}{l}\text { Satis- } \\
\text { faction }\end{array}$ & 0.429 & 0.473 & 0.471 & 0.420 & 0.330 & 0.418 \\
\hline
\end{tabular}

A stepwise regression analysis was conducted for the satisfaction results. The Table 10 below shows the results of the stepwise regression when only the first subscale of the satisfaction index was taken into account. The analysis shows that most important factors influencing the student satisfaction towards the program is Faculty-Student Interaction followed by Student-Student Interaction and further followed by Personal relevance. In stepwise regression analysis the least significant factors are removed and only the factors with the most significant effect on the responses are displayed.

Table 10 Stepwise regression for Student satisfaction

\begin{tabular}{|l|c|c|c|c|}
\hline \multicolumn{1}{|c|}{ Factors } & DF & SS & F value & P value \\
\hline $\begin{array}{l}\text { Faculty-Student } \\
\text { Interaction }\end{array}$ & 3 & 12.213 & 10.77 & 0.001 \\
\hline $\begin{array}{l}\text { Student-Student } \\
\text { Interaction }\end{array}$ & 1 & 3.729 & 3.29 & 0.073 \\
\hline $\begin{array}{l}\text { Students' } \\
\text { Personal } \\
\text { Behaviour }\end{array}$ & 1 & 4.722 & 4.17 & 0.044 \\
\hline
\end{tabular}

The residual plot and the normal probability plots for the regression analysis are shown in the Figure 8. The normal probability shows that all the points are uniformly distributed along the mean line and this represents a good 
fit. The histogram also shows that the points are uniformly distributed along the centre line and this indicates a good fit of the data. The analytical relationship between the student satisfactions is also represented in the form of equation as shown below,

Satisfaction $=-0.634+0.505 *$ Faculty-Student Interaction $+0.305 *$ Student-Student Interaction $+0.342 *$ Students' Personal Behaviour

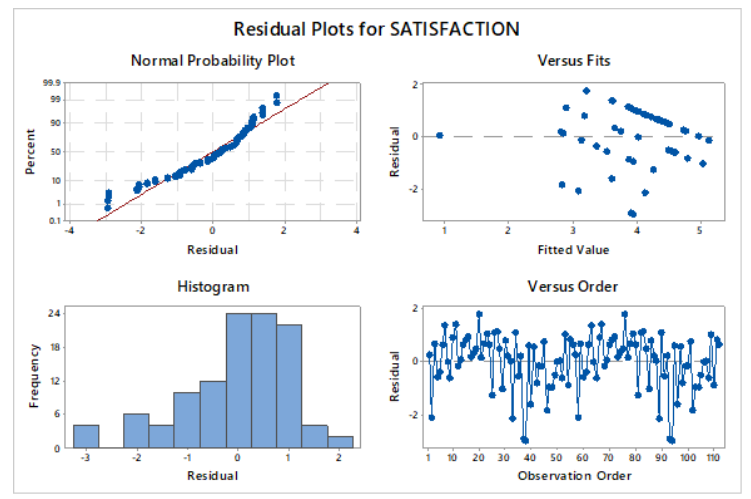

Fig. 8 Residual plots for the satisfaction analysis

The same stepwise regression analysis was conducted with the aggregated satisfaction index and the results have been represented in the Table 11 . Here also it is observed that Faculty-Student interaction and Student-Student interaction are the most significant factors affecting the overall satisfaction of the students.

Table 11 Stepwise regression for student satisfaction index

\begin{tabular}{|l|c|c|c|c|}
\hline \multicolumn{1}{|c|}{ Factors } & DF & SS & $\begin{array}{c}\text { F- } \\
\text { Value }\end{array}$ & $\begin{array}{c}\text { p- } \\
\text { Value }\end{array}$ \\
\hline $\begin{array}{l}\text { Faculty- } \\
\text { Student } \\
\text { Interaction }\end{array}$ & 2 & 5.152 & 5.90 & 0.017 \\
\hline $\begin{array}{l}\text { Student- } \\
\text { Student } \\
\text { Interaction }\end{array}$ & 1 & 19.676 & 19.44 & 0.000 \\
\hline
\end{tabular}

The residual plot and the normal probability plots for the regression analysis are shown in the Figure 9. The normal probability shows that all the points are uniformly distributed along the mean line and this represents a good fit. The histogram also shows that the points are uniformly distributed along the centre line and this indicates a good fit of the data.

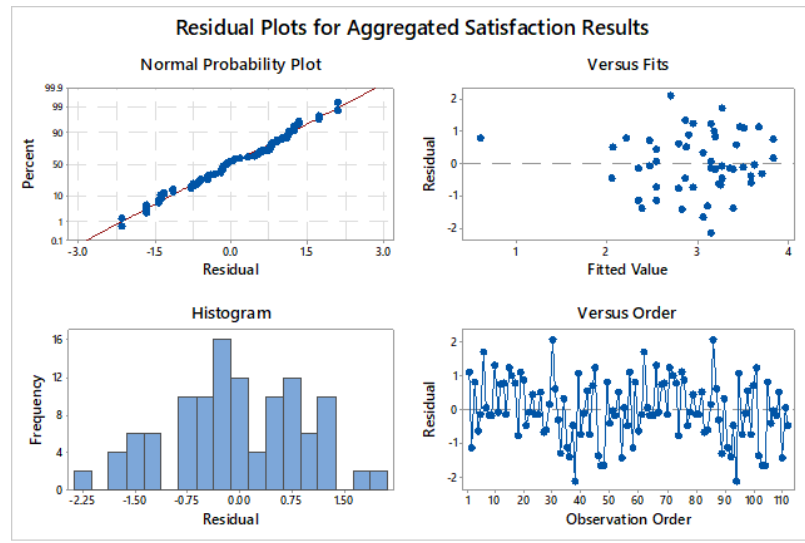

Fig. 9 Residuals and normal probability plot for aggregated satisfaction index

Two analysis for satisfaction of students was carried out and it was observed that Teacher-Student Interaction and Student-Student Interaction are the most significant factors. Hence a further analysis of the subscales for the respective factors is carried out.

\section{Teacher student interaction}

Regression analysis of the student satisfaction was carried out where the subscales of Teacher-Student Interaction were taken as the input factors. It was observed from the analysis that three subscales namely "The faculty responds promptly to my questions", "Faculty gives me feedback on my assignments" and "The faculty is approachable and it is easy to contact the faculty" were the most significant factors affecting the results for satisfaction of the students. The pvalues of the factors indicate that the results are true. The details from the regression analysis have been detailed in the Table 12.

Table 12 Stepwise regression of Teacher-StudentInteraction

\begin{tabular}{|l|c|c|c|c|}
\hline $\begin{array}{c}\text { Factors / } \\
\text { Subscales }\end{array}$ & DF & SS & $\begin{array}{c}\text { F- } \\
\text { value }\end{array}$ & $\begin{array}{c}\text { p- } \\
\text { value }\end{array}$ \\
\hline $\begin{array}{l}\text { The faculty } \\
\text { responds to my } \\
\text { promptly to } \\
\text { questions }\end{array}$ & 1 & 5.224 & 4.06 & 0.046 \\
\hline $\begin{array}{l}\text { The faculty gives } \\
\text { me feedback on } \\
\text { my assignments }\end{array}$ & 1 & 3.011 & 2.34 & 0.129 \\
\hline $\begin{array}{l}\text { The faculty is } \\
\text { approachable } \\
\text { and it is easy to } \\
\text { contact the } \\
\text { faculty }\end{array}$ & 1 & 9.524 & 7.41 & 0.008 \\
\hline
\end{tabular}

\section{Student-student interaction}

Similarly a stepwise regression analysis was conducted on the sub-scales of the Student-Student Interaction and among the six sub-scales the three scales mentioned in the Table 13 were found as the most significant parameters affecting the student satisfaction. "I share information with other students" is the most critical sub-scale followed by "I discuss ideas with other students" followed by "I 
collaborate with other students in the class" as the third most important parameter.

Table 13 Stepwise regression analysis of StudentStudent Interaction

\begin{tabular}{|l|c|c|c|c|}
\hline \multicolumn{1}{|c|}{$\begin{array}{c}\text { Factors / } \\
\text { Subscales }\end{array}$} & DF & SS & $\begin{array}{c}\text { F- } \\
\text { value }\end{array}$ & $\begin{array}{c}\text { P- } \\
\text { value }\end{array}$ \\
\hline $\begin{array}{l}\text { I share } \\
\text { information } \\
\text { with other } \\
\text { students }\end{array}$ & 1 & 13.282 & 12.16 & 0.001 \\
\hline $\begin{array}{l}\text { I discuss my } \\
\text { ideas with other } \\
\text { students }\end{array}$ & 1 & 11.165 & 10.22 & 0.002 \\
\hline $\begin{array}{l}\text { I collaborate } \\
\text { with other } \\
\text { students in the } \\
\text { class }\end{array}$ & 1 & 4.328 & 3.96 & 0.049 \\
\hline
\end{tabular}

\section{Conclusions}

This study was implemented for analyzing the feedback from the students regarding the current online teaching methodology that is being followed in our university. The pandemic had forced the university to adopt online teaching process in a swift way and this analysis will help us in understanding how the student is coping up with the recent online teaching methodology. Feedback was collected from 112 respondents and various factors such as 'FacultyStudent Interaction', 'Student-Student Interaction', 'Students' Personal Behaviour', 'Real world learning', 'Student learning strategy', 'Student Learning Approach' was taken into account for determining the Student Satisfaction towards the course. Each of these factors were divided in to subscales and these subscales were included in the survey. The detailed analysis of each of these subscales was conducted and the highlights are,

1. In Faculty-Student interaction the overall score was good and the subscale found lagging was "Faculty gives feedback on assignments".

2. Student-Student interaction is one scale which needed improvement as it was observed that this online model of teaching had led to less interaction between the students. Such an issue is not prevalent in offline teaching as the students are always present in the vicinity of each other and find it easy to discuss and interact more.

3. Stepwise regression analysis of the Student Satisfaction was conducted and it was observed that FacultyStudent Interaction and Student-Student interaction are the two factors which were found to be the most influencing the most with regards to student satisfaction as per the analysis.

4. Correlation analysis was conducted and the significant relationships between the different factors have been indicated.
5. Teacher-Student Interaction was further analyzed using regression and the three factors "Faculty responds promptly to my questions", "Faculty gives me feedback on my assignments" and "Faculty is approachable and it is easy to contact the faculty" were the most significant factors.

6. Student-Student Interaction was further analyzed using regression and the three factors "I share information with other students", "I discuss my ideas with other students" and "I collaborate with other students in the class" were the most significant factors affecting the Student Satisfaction.

7. Satisfaction was divided into 5 subscales with the first subscale "I am satisfied with this program" is considered as the most important factor and the mean rating was a respectable 3.98. The other subscales have received a poor rating when compared to this.

8. Subscales in satisfaction such as "Online education is worth my time", "I enjoy studying online", "Online education is exciting" and others are statements which shall gain higher preference only when online classes are conducted for longer durations and the student completely becomes convenient and familiar with the idea of online classes.

9. As the online class scenario was something which was forced on to due to the pandemic, expecting students or faculty to say that they have completely enjoyed the experience and will be willing to further continue with the same is not expected immediately and will take some more time.

\section{References}

$\tilde{A}$, M. J. H., Kleiner, C. and Hess, R. F. (2006) 'The experience of nursing students in an online doctoral program in nursing: A phenomenological study', 43, pp. 99-105. doi: 10.1016/j.ijnurstu.2005.03.001.

Beyth-Marom, R. et al. (2003) 'Internet-assisted versus traditional distance learning environments: Factors affecting students' preferences', Computers and Education, 41(1), pp. 65-76. doi: 10.1016/S0360-1315(03)00026-5.

Hermans, C. M., Haytko, D. L. and Mott-stenerson, B. (2009) 'Student Satisfaction in Web-enhanced Learning Environments', Journal of Instructional Pedagogies, 1, pp. 1-19. Available at: http://www.aabri.com/manuscripts/09147.pdf.

Kalpokaite, N. and Radivojevic, I. (2020) 'Teaching qualitative data analysis software online: a comparison of face-to-face and e-learning ATLAS.ti courses', International Journal of Research and Method in Education. Taylor \& Francis, 43(3), pp. 296-310. doi: 10.1080/1743727X.2019.1687666.

Kuo, Y. et al. (2013) 'A predictive study of student satisfaction in online education programs | Kuo | The International Review of Research in Open and Distributed Learning', The International Review of Research in Open and Distance Learning, 14(1). Available at: 
http://www.irrodl.org/index.php/irrodl/article/view/1338/2

416.

Mahmud, M. S., Khan, A. G. and Lima, R. P. (2018) 'Measuring students' satisfaction in the Universities of Bangladesh : An empirical analysis', International Journal of Multidisciplinary Research and Development, 5(6), pp. 30-38.

Moore, M. G. (1989) 'Three Types of Interaction', American Journal of Distance Education, 3(2), pp. 1-7. doi: $10.1080 / 08923648909526659$.

Palmer, S. R. and Holt, D. M. (2009) 'Examining student satisfaction with wholly online learning', Journal of Computer Assisted Learning, 25(2), pp. 101-113. doi: 10.1111/j.1365-2729.2008.00294.x.

Sharp, J. H. and Huett, J. B. (2005) 'Importance of learnerlearner interaction in distance education', Information systems education journal, 4(26). doi: http://isedj.org/4/46/.

da Silva, L. F. C., Barbosa, M. W. and Gomes, R. R. (2019) 'Measuring Participation in Distance Education Online Discussion Forums Using Social Network Analysis', Journal of the Association for Information Science and Technology, 70(2), pp. 140-150. doi: 10.1002/asi.24080.

Strong, R. (2012) 'Investigating Students' Satisfaction with eLearning Courses: The Effect of Learning Environment and Social Presence', Journal of Agricultural Education, 53(3), pp. 98-110. doi: 10.5032/jae.2012.03098.

Villegas-Ch, W., Román-Cañizares, M. and PalaciosPacheco, X. (2020) 'Improvement of an online education model with the integration of machine learning and data analysis in an LMS', Applied Sciences (Switzerland), 10(15). doi: 10.3390/APP10155371.

Walker, S. L. and Fraser, B. J. (2005) 'Development and validation of an instrument for assessing distance education learning environments in higher education: The Distance Education Learning Environments Survey (DELES)', Phenomenology and the Cognitive Sciences, 4(3), pp. 289308. doi: 10.1007/s10984-005-1568-3.

Young, S. (2010) 'Student Views of Effective Online Teaching in Higher Education', American Journal of Distance Education, 3647(December 2014), pp. 37-41. doi: 10.1207/s15389286ajde2002. 